\title{
Requirements of Health Data Management Systems for Biomedical Care and Research: Scoping Review
}

Leila Ismail ${ }^{1}, \mathrm{PhD}$; Huned Materwala ${ }^{1}, \mathrm{MS} ;$ Achim P Karduck ${ }^{2}, \mathrm{PhD} ; \mathrm{Abdu} \mathrm{Adem}^{3}, \mathrm{PhD}$

${ }^{1}$ Department of Computer Science and Software Engineering, College of Information Technology, United Arab Emirates University, Al Ain, Abu Dhabi, United Arab Emirates

${ }^{2}$ Faculty of Informatics, Furtwangen University, Furtwangen, Germany

${ }^{3}$ College of Medicine and Health Sciences, United Arab Emirates University, Al Ain, Abu Dhabi, United Arab Emirates

\section{Corresponding Author:}

Leila Ismail, $\mathrm{PhD}$

Department of Computer Science and Software Engineering

College of Information Technology

United Arab Emirates University

Al Maqam Campus

Al Ain, Abu Dhabi, 15551

United Arab Emirates

Phone: 97137673333 ext 5530

Email: leila@uaeu.ac.ae

\section{Abstract}

Background: Over the last century, disruptive incidents in the fields of clinical and biomedical research have yielded a tremendous change in health data management systems. This is due to a number of breakthroughs in the medical field and the need for big data analytics and the Internet of Things (IoT) to be incorporated in a real-time smart health information management system. In addition, the requirements of patient care have evolved over time, allowing for more accurate prognoses and diagnoses. In this paper, we discuss the temporal evolution of health data management systems and capture the requirements that led to the development of a given system over a certain period of time. Consequently, we provide insights into those systems and give suggestions and research directions on how they can be improved for a better health care system.

Objective: This study aimed to show that there is a need for a secure and efficient health data management system that will allow physicians and patients to update decentralized medical records and to analyze the medical data for supporting more precise diagnoses, prognoses, and public insights. Limitations of existing health data management systems were analyzed.

Methods: To study the evolution and requirements of health data management systems over the years, a search was conducted to obtain research articles and information on medical lawsuits, health regulations, and acts. These materials were obtained from the Institute of Electrical and Electronics Engineers, the Association for Computing Machinery, Elsevier, MEDLINE, PubMed, Scopus, and Web of Science databases.

Results: Health data management systems have undergone a disruptive transformation over the years from paper to computer, web, cloud, IoT, big data analytics, and finally to blockchain. The requirements of a health data management system revealed from the evolving definitions of medical records and their management are (1) medical record data, (2) real-time data access, (3) patient participation, (4) data sharing, (5) data security, (6) patient identity privacy, and (7) public insights. This paper reviewed health data management systems based on these 7 requirements across studies conducted over the years. To our knowledge, this is the first analysis of the temporal evolution of health data management systems giving insights into the system requirements for better health care.

Conclusions: There is a need for a comprehensive real-time health data management system that allows physicians, patients, and external users to input their medical and lifestyle data into the system. The incorporation of big data analytics will aid in better prognosis or diagnosis of the diseases and the prediction of diseases. The prediction results will help in the development of an effective prevention plan.

(J Med Internet Res 2020;22(7):e17508) doi: $\underline{\text { 10.2196/17508 }}$ 


\section{KEYWORDS}

big data; blockchain; data analytics; eHealth; electronic medical records; health care; health information management; Internet of Things; medical research; mHealth

\section{Introduction}

The notion of health data management systems has evolved during the last century. With the evolution of medical records from paper charts to electronic health records (EHRs) [1], health data management has undergone disruptive transitions to provide more accurate and better patient care and make qualitative use of these records. This shift is underpinned by the advancement in information technologies that led to the development of several notions of health data management systems. Those health data management systems were often misaligned with the goals of biomedical care and research. This misalignment is caused particularly by the discrepancies between advanced technologies and their adoption for biomedical care and research. Consequently, it becomes vital to address this gap by developing a new framework for the health data management system. In this paper, we provide a broader history and evolution of health data management systems underpinned by the changing definition of medical records, discuss the issues prevailing within, introduce the modern aspects of health data management systems supporting the growing size of medical data, and discuss insights and provide solutions aiming for a better health care ecosystem.

The introduction of EHRs has transformed the health care industry by providing more services, improving the quality of patient care, and enhancing the data access ability in real time, thereby creating a diverse set of health data management systems [2]. Our understanding of EHRs is that it provides a longitudinal view of a patient's medical history over his or her lifetime generated by one or more health care providers or medical organizations delivering treatments to that patient. These cohesive and summarized records include the patient's demographic and personal information, past and current diagnoses and treatments, progress notes, laboratory and radiology results, allergies, and immunizations [1]. However, an earlier form of EHRs referred to as paper charts involves written records of a patient's diagnosis and treatments for the purpose of medical teaching. Next, the term has been revised to computer-based patient records, electronic medical records, and currently EHRs. With the advancement in technological developments and the goal to provide better and efficient health care, health data management systems have evolved from a computer-based approach to client-server-based, cloud, the Internet of Things (IoT), and finally to blockchain-based system.

With the rise of big health care data and the realization of using medical data for governance and research, it becomes necessary to integrate big data analytics within health data management systems [3]. However, this brings new challenges of data aggregation and preprocessing from multiple sources to develop insights, data security, and privacy to cope with an increasing number of data breaches and hacking incidents [4]. Further challenges have been imposed on biomedical care and research by the nature and types of medical data being generated at a rapid pace. These challenges have developed the need for a new health data management framework.

This paper analyzes the requirements for better patient care and predictive analysis that must be considered when implementing a health data management system. Considering these requirements will make the health care data management system more accurate, efficient, and cost-effective. To our knowledge, this is the first analysis of the temporal evolution of health data management systems to give insights into the system requirements for better health care.

The contributions of this paper are three-fold. First, the paper provides a taxonomy of health data management systems based on their technological advancement, and the inherent challenges and issues are discussed therein. Second, we present the reforming definitions of medical records and extract the requirements of a health data management system. Third, the paper provides insights into the health data management system research and guidelines for the future research area.

\section{Related Works}

Health data management systems are evolving for better health care. Literature reviews on these systems are classified into 2 categories: (1) electronic health (eHealth) [5-8] and (2) mobile health (mHealth) [9].

Regarding eHealth, the study by Jamal et al [5] reviews the impact of a computerized system on the quality of health care. The results showed that a health information system, if properly designed, can prevent medical errors and can support doctors and medical providers in diagnosis. The study by Van De Belt et al [6] reviews the definitions of health and medicine over 2 years (from 2007 to 2009), coming up with a common definition involving the web, patients, professionals, social networking, health information content, and collaboration. In this study, we reveal additional requirements needed for better health care: privacy, security, public insights, and patient participation in accessing and monitoring medical data. The studies by Hans et al [7] and Cunningham et al [8] focus on the definitions of eHealth from 1999 to 2004 . The authors found that the themes health and technologies are most recurrent in all definitions.

Concerning mHealth, Silva et al [9] provide a review of mHealth apps and services. It highlights that the coordination, integration, and interoperability between different mHealth apps is important for better health care as well as improved performance of mobile devices in terms of device battery, storage, computation, and network.

In this study, we reviewed health data management systems based on the following 7 requirements across studies conducted over the years: (1) medical record data, (2) real-time data access, (3) patient participation, (4) data sharing, (5) data security, (6) patient identity privacy, and (7) public insights. 


\section{Methods}

For the analysis and study of the evolution of health data management systems, we reviewed published research articles, reports, medical lawsuits, and health care regulations; acts about the methods of organizing medical record data; and the needs of a health data management system. The literature was searched in the Institute of Electrical and Electronics Engineers, Association for Computing Machinery, Elsevier, MEDLINE, PubMed, Scopus, and Web of Science databases from 1793 to 2020. We selected the papers that included incidents that involved the definitions of a health data management system, triggered the introduction of a new system, and/or implemented technologies for better health care. The analysis of these papers shows that advances in technologies are being adopted for accurate and efficient patient care.

\section{Results}

\section{Taxonomy of Health Data Management Systems}

Before satisfying the requirements of biomedical care and research, the evolution of the underlying health data management systems and their limitations must be understood. The capabilities of the health data management should ensure that the requirements of patient care are met. Health data management systems have undergone multiple transitions over the years alongside the advancement in information technologies as shown in Figure 1. During this evolution, several programs were established and regulation acts were passed to improve the quality of patient care. Table 1 presents the events that triggered the evolution of health data management systems. Table 2 presents the limitations of health data management systems. 
Figure 1. Evolution of the health data management system.

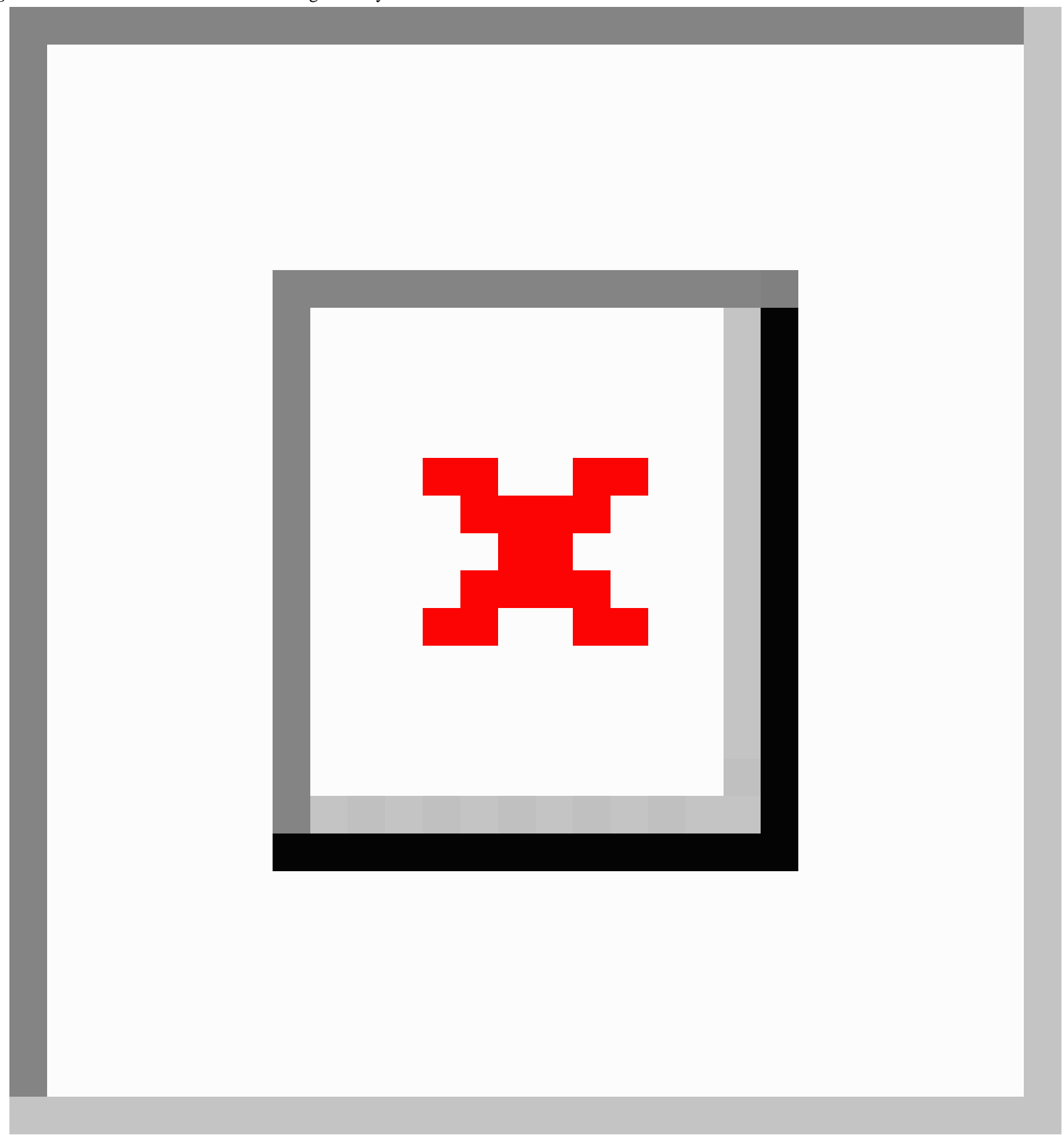


Table 1. Events that have triggered the evolution of health data management systems.

\begin{tabular}{lll}
\hline Year & Responsible authority & \begin{tabular}{l} 
Evolutionary change \\
\hline 1793
\end{tabular} \\
$\begin{array}{l}\text { Board of Governors of the Society of } \\
\text { the New York Hospital }\end{array}$ & $\begin{array}{l}\text { Rule to record patients' data for hospital expenditure justification was passed [10]. } \\
\text { Board of Governors of the Society of of } \\
\text { the New York Hospital }\end{array}$ & $\begin{array}{l}\text { Rule to record major medical cases for education was passed provoked by a fatal dispute between } \\
\text { an American statesman and an American politician. According to the rule, the recorded cases } \\
\text { should be bounded in a book for inspection by the governors, medical professionals and students, } \\
\text { and the friends of the patients [11]. }\end{array}$
\end{tabular}

1830 Board of Governors of the Society of Rule to maintain a record of all the medical cases [11]. the New York Hospital

1918 American College of Surgeons

1928 American College of Surgeons

The 1960s Lawrence Weed

The 1960s N/A

1965 Centers for Medicare and Medicaid Services

1965 Lockheed Corporation

University of Utah, 3M and LatterDay Saints Hospital

Massachusetts General Hospital and Harvard University

The 1980s Indian Health Service

$1987 \quad$ Health Level Seven

1991 Institute of Medicine

$1996 \quad$ US Congress

$1999 \quad$ John Mitchell

2000 S Laxminarayan and Robert SH Istepanian

$2001 \quad$ Gunther Eysenbach

$2004 \quad$ Stephen S Intille

The 2000s Health care organizations

$2003 \quad$ Institute of Medicine
A hospital standardization program was established to standardize the format of medical records for improved patient care [12].

American Association of Record Librarians of North America was established to enhance the standards of medical records [13].

The idea to use computers for medical records was proposed to allow doctors to track a patient's medical history and provide evidence for the treatment [14].

A problem-oriented medical records model was developed to standardize the method of EMRs ${ }^{\mathrm{a}}$ that provided a structure to help doctors record their notes [14].

Paper charts were termed as EMRs.

Rule to record patients' data by medical nurses for medical insurance reimbursement with the introduction of Medicare and Medicaid laws [15].

First commercial computerized health data management system known as Clinical Information System was developed for El Camino Hospital. The system included features for laboratory tests, appointment scheduling, and pharmacy management [16].

First clinical decision support system known as Health Evaluation of Logical Processing was developed to support clinical operations. The system helped doctors to identify cardiac contraction based on a patient's test results' analysis and to select an appropriate medication for infectious disease cases [17].

The first modular computer-based health data management system known as Computer Stored Ambulatory Record was implemented. The system accommodated clinical vocabularies through clinical mapping to recognize different terms used for the same disease [18].

$\mathrm{MPI}^{\mathrm{c}}$ was introduced to keep track of patients' medical data to reduce unnecessary testing and adverse drug effects [19].

Electronic standards were developed to address the standardization issues of health data management system development and adaption. The standards allowed the use of components from different vendors in a health data management system [20].

The term computer-based patient records was introduced in a report studying the benefits of electronic management of health records [21].

The Health Insurance Portability and Accountability Act was passed to safeguard patients' medical records by involving role-based access control, automatic data backup, audit trails, and data encryption [22].

The term eHealth ${ }^{\mathrm{d}}$ was coined that refers to the integration of electronic communication and information technologies for electronic transmission, storage, and retrieval of medical records both locally and remotely [23].

The term mHealth ${ }^{\mathrm{e}}$ was coined that refers to wireless telemedicine using mobile telecommunications and multimedia technologies for the new mobile health care system [24].

The definition of eHealth was expanded by incorporating business and public health to health services and defining the outcomes and stakeholders of eHealth [25].

The term uHealth ${ }^{\mathrm{f}}$ was coined that refers to the use of biometric sensors and medical devices to monitor and improve a patient's medical health [26].

Proposed a formal definition of the term personal health records that allows patients to access their medical history and to manage it by making part of it available to selected participants by defining access control rights [27].

The term electronic health records [28] was coined. 


\begin{tabular}{lll}
\hline Year & Responsible authority & Evolutionary change \\
\hline 2006 & Commonwealth of Massachusetts & $\begin{array}{l}\text { Massachusetts health care reform law was passed that mandated for residents to have minimum } \\
\text { medical insurance coverage and for employers with more than 10 full-time employees to provide } \\
\text { medical insurance coverage [29]. }\end{array}$ \\
2006 & Elliott Fisher & $\begin{array}{l}\text { The term Accountable Care Organizations was coined that refers to a group of doctors, hospitals, } \\
\text { and other health care providers who volunteer to give high-quality care to their patients to avoid } \\
\text { unnecessary duplication of services and reduce medical errors [30]. }\end{array}$ \\
2009 & $\begin{array}{l}\text { US Department of Justice, Office of } \\
\text { Inspector General, and Human and }\end{array}$ & $\begin{array}{l}\text { The Health care Fraud Prevention and Enforcement Action was established to strengthen the } \\
\text { existing programs to prevent and reduce Medicare and Medicaid frauds [31]. }\end{array}$ \\
Health Services & US President Barack Obama & $\begin{array}{l}\text { The Patient Protection and Affordable Care Act was signed into law with an objective to provide } \\
\text { an expansion of medical insurance coverage [32]. }\end{array}$ \\
\hline
\end{tabular}

${ }^{\mathrm{a}} \mathrm{EMR}$ : electronic medical record.

${ }^{\mathrm{b}} \mathrm{N} / \mathrm{A}$ : not applicable.

${ }^{\mathrm{c}} \mathrm{MPI}$ : master patient index.

$\mathrm{d}_{\text {eHealth: electronic health. }}$

e mHealth: mobile health.

fuHealth: ubiquitous health

Table 2. Limitations of health data management systems.

\begin{tabular}{|c|c|}
\hline $\begin{array}{l}\text { Health data management } \\
\text { system }\end{array}$ & Limitation \\
\hline Paper charts & $\begin{array}{l}\text { Illegible handwriting resulting in incorrect treatments [33] and deaths [34,35]. Requires physical storage and are sus- } \\
\text { ceptible to unplanned destruction such as flood, fire, rodents, and degradation. Physically cumbersome to read, understand, } \\
\text { and search for specific information. The cost and time required for paper charts to be requested for duplication and then } \\
\text { delivered are unacceptably high. }\end{array}$ \\
\hline Computer-based & $\begin{array}{l}\text { Medical records are managed by the physicians and cannot be accessed by the patients. Physicians visiting a patient } \\
\text { have to note down or memorize the patient's medical data to return to the hospital and record it digitally, which may } \\
\text { lead to error. }\end{array}$ \\
\hline Client-server-based & $\begin{array}{l}\text { A patient has no traceability on how his or her data are used. The issues of security, privacy, and single point of failure. } \\
\text { In addition, a cohesive view of a patient's medical data from multiple hospitals is difficult. Requires repeating medical } \\
\text { tests at times, which results in more time, cost, and effect on health conditions. }\end{array}$ \\
\hline Cloud-based & $\begin{array}{l}\text { Single point of failure, loss of data control and stewardship, a requirement of steady internet connection, and data reli- } \\
\text { ability }[36,37] \text {. }\end{array}$ \\
\hline IoT $^{\mathrm{a}}$-based & Data security and patient privacy are a major concern. \\
\hline Big-data-based & $\begin{array}{l}\text { The process of data aggregation from different storage sites is time consuming, complex, and expensive. The data are } \\
\text { stored using different formats and requires preprocessing. In addition, preserving the security of the data and privacy } \\
\text { of the patient identity while maintaining the usefulness of data for analysis and studies is quite challenging. }\end{array}$ \\
\hline Blockchain-based & $\begin{array}{l}\text { The process of ledger update on multiple nodes is energy consuming [38] and suffers from the issue of low throughput } \\
\text { [39]. }\end{array}$ \\
\hline
\end{tabular}

${ }^{\mathrm{a}}$ IoT: Internet of Things.

\section{Requirements of a Health Data Management System}

Over the last century, the definition of health data management has undergone numerous reformations to address the need for better and advanced patient care alongside technological advances. We evaluated these differing examinations and rationalized the definition used in the remainder of the paper. It is important to note that, as the term health data management is rather recent, the listed definitions were taken from different legislations and health data recording systems, even if the exact phrase health data management was not used. Table 3 shows the evolving definitions of health data management systems from being purely medical practice and learning-based definitions to being more patient-centric and research-based definitions. We classified health data management systems based on 7 requirements that underpin the evolution in the field as shown in Figure 2. Each number in the figure represents a definition stated in Table 3. 
Table 3. The definitions of health data management systems.

\begin{tabular}{llll}
\hline Number & Year & Source & Definition \\
\hline 1 & 1793 & Siegler [10] & $\begin{array}{l}\text { "[...] Names and Diseases of the Persons, received, deceased or discharged in the same, with the date of } \\
\text { each event, and the Place from whence the Patients last came [...]" } \\
\text { "The house physician, with the aid of his assistant, under the direction of the attending physician, shall keep } \\
\text { a register of all medical cases which occur in the hospital, and which the latter shall think worthy of } \\
\text { preservation, which book shall be neatly bound, and kept in the library for the inspection of the friends of } \\
\text { the patients, the governors, physicians and surgeons, and the students attending the hospital." }\end{array}$
\end{tabular}

"Accurate and complete medical records [...] which includes identification data; complaint; personal and [12] family history; history of the present illness; physical examination; special examinations such as consultations, clinical laboratory, $\mathrm{x}$-ray and other examinations; provisional or working diagnosis; medical or surgical treatment; gross or microscopical pathological findings; progress notes; final diagnosis; condition on discharge; follow-up; and, in case of death, autopsy findings."

"The computer is making a major contribution [...] the patient will gain from his physician an immediate sympathetic understanding [...] inadequate analysis by the medical profession can be avoided."

“[...] orient data around each problem [...] complete list of all the patient's problems [...] diagnosis and all other unexpected findings or symptoms [...] The list is separated into active and inactive problems, and in this way, those of immediate importance are easily discernible [...] orders, plans, progress notes and numerical data can be recorded under the numbered and titled problem [...]"

"Digital versions of paper charts that contain the medical and treatment history of the patients from one practice for providers to use for diagnosis and treatment"

"Electronic patient record [...] support users through availability of complete and accurate data, practitioner reminders and alerts, clinical decision support systems, links to bodies of medical knowledge, and other aids."

"[...] medical informatics, public health and business, referring to health services and information delivered or enhanced through the Internet and related technologies [...] an attitude, and a commitment for networked, global thinking, to improve health care locally, regionally, and worldwide by using information and communication technology."

"The subjective component contains information about the problem [...] objective information consists of Song [41] those observations made by the counselor [...] assessment section demonstrates how [...] data are formulated, interpreted, and reflected upon, and the plan section summarized the treatment direction."

"[...] electronic application through which individuals can access, manage and share their health information, [42] and that of others for whom they are authorized, in a private, secure, and confidential environment.'

"[...] longitudinal electronic record of patient health information generated by one or more encounters [...] patient demographics, progress notes, problems, medications, vital signs, past medical history, immunizations, laboratory data and radiology reports [...] automates and streamlines the clinician's workflow. The EHRs has the ability to generate a complete record of a clinical patient encounter [...] evidence-based decision support, quality management, and outcomes reporting."

"The Electronic Health Record (EHR) is a secure, real-time, point-of-care, patient-centric information resource $[\ldots]$ decision making by providing access to patient health record information where and when they need it and by incorporating evidence-based decision support [...] billing, quality management, outcomes reporting, resource planning, and public health disease surveillance and reporting."

$2005 \quad$ AHIMA $^{\mathrm{b}}[44]$

“[...] lifelong resource of health information needed by individuals to make health decisions. Individuals own and manage the information [...] is maintained in a secure and private environment, with the individual determining rights of access $[\ldots]$ "...

$2008 \quad$ Böcking and Tro-

"Health data management [...] acquiring, entering, processing, coding, outputting, retrieving, and storing janus [45] of data gathered in the different areas of health care [...] also embraces the validation and control of data according to legal or professional requirements."

$2013 \quad$ HIPAA $^{\mathrm{c}}[22]$

“A major goal [...] to protect the privacy of individuals' health information [...] adopt new technologies to improve the quality and efficiency of patient care."

${ }^{\mathrm{a}}$ HIMSS: Healthcare Information and Management Systems Society.

${ }^{b}$ AHIMA: American Health Information Management Association.

${ }^{\mathrm{c}}$ HIPAA: Health Insurance Portability and Accountability Act. 
Figure 2. Requirements of a health data management system.



\section{Medical Record Data}

Medical record data that describes the identity and health of a patient based on the personal and demographic identity, history of the medical condition, ongoing treatment, laboratory tests, and radiology results are the common requirement of a health data management system. The medical records have been a primary component throughout the evolution of health data management systems, whether in the form of printed documents or digital records.

\section{Real-Time Data}

To improve the quality of patient care, the requirement of real-time data access was highlighted in the definitions of health data management systems. This requirement reduces the medical incidents owing to the delay in data updates by the physicians. However, this requirement cannot be fulfilled by the paper-based and computer-based health data management systems. This requirement was introduced with the client-server-based management system [46-52] that enables the physicians to access and update the patient medical records in real time.

\section{Patient Participation}

With the medical records maintained by the hospitals or third-party cloud service providers, the patients cannot track how their medical data are used. Consequently, patient participation in accessing and monitoring medical data is a key requirement to develop trust in health data management systems. In addition to data access, the participation of patients in providing health conditions and lifestyle data to the physicians will aid in better prognosis and diagnosis. The introduction of IoT-based health data management system involving sensors and medical devices that monitor a patient's health and lifestyle conditions enables the patient to input their medical conditions to the system [53-59]. An analysis of personal health records management platforms based on users' perception shows that a simple easy-to-use system is required for patient engagement and satisfaction [60].

\section{Sharing}

Sharing of medical records is a vital requirement with the patient's treatment being spread across various health care providers. This is to aid other physicians to study the patient's medical history for better treatment and to avoid repetition of laboratory and radiology tests. On the basis of the list of definitions in Table 3, we classified sharing based on the users allowed to access the data into 3 different categories: (1) degree 1 , where the information is shared within the same medical organization where the patient is currently receiving treatment, (2) degree 2, where the information is shared with the patient, patient's friends, and family, and (3) degree 3, where the information is shared with other medical organizations and government. The requirement of sharing is complemented by the introduction of the cloud-based health data management system [61-63]. However, to share medical record data between different health care organizations and to efficiently use the shared information, the systems should support interoperability. Interoperability can be achieved by using a standard format to store, manage, and share the medical data. There are several standard formats to store medical data and images [64]. Some of the major file formats used for medical images are Analyze [65], Neuroimaging Informatics Technology Initiative [66], Minc [67], and Digital Imaging and Communications in Medicine [68]. Health Level 7 International, standardized by the American National Standards Institute, is a health care protocol for sharing medical data [20]. It includes the rules for the integration, exchange, and management of EHRs. Wen et al [69] assessed the interoperability of eHealth systems in Taiwan for exchanging data. This is to reduce repeated medical examinations and medications for better health care. They concluded that the government should define policies to enforce interoperability.

\section{Security}

With increasing incidents of data breaching and phishing attacks, and the adoption of a third-party service provider, the security of the patients' sensitive and important data is essential. Compared with 477 health data breaches reported in 2017, 
affecting 5,579,438 patient records in 2017, 503 breaches affecting 15,085,302 records were reported in 2018 [70]. The requirement of security is even high when patients' medical records are handled by a cloud service provider or when medical sensors and devices are used to gather patients' medical and lifestyle data. According to a report by Intel Security, the use of cloud services by the health care provider has reduced owing to the lack of cyber security methods implemented by the cloud service provider [71]. A report states that, on average, hospitals lose track of around $30 \%$ of their networked medical devices, making it much harder to protect against vulnerabilities [72]. More than $61 \%$ of all IoT devices and sensors on a hospital network are at high risk of cyber-attack. In recent years, blockchain technology $[73,74]$ has gained wide popularity and has penetrated into the domain of health care to address the need for a more patient-centric supportive system for the professionals, to connect disparate systems for improved patient care, and to increase the accuracy of EHRs [75-81].

\section{Privacy}

The privacy requirement of a patient's identity in a health data management system is crucial with the increasing number of medical frauds and fake medications. The privacy of the patient cannot be compromised, especially with the rise of data analytics, where the medical record data of the patients are used for analysis. The blockchain-based health data management system aims to address this issue.

\section{Public Insights}

Prediction of health conditions is important to avoid life-threatening situations. The increasing amount of health care data [82], if properly analyzed, can facilitate the prediction of health conditions. The process of gathering, organizing, storing, and analyzing big data to discover correlations, hidden patterns, and other valuable insights is known as big data analytics. Figure 3 shows the life cycle of big data analytics. 
Figure 3. Lifecycle of big data analytics.

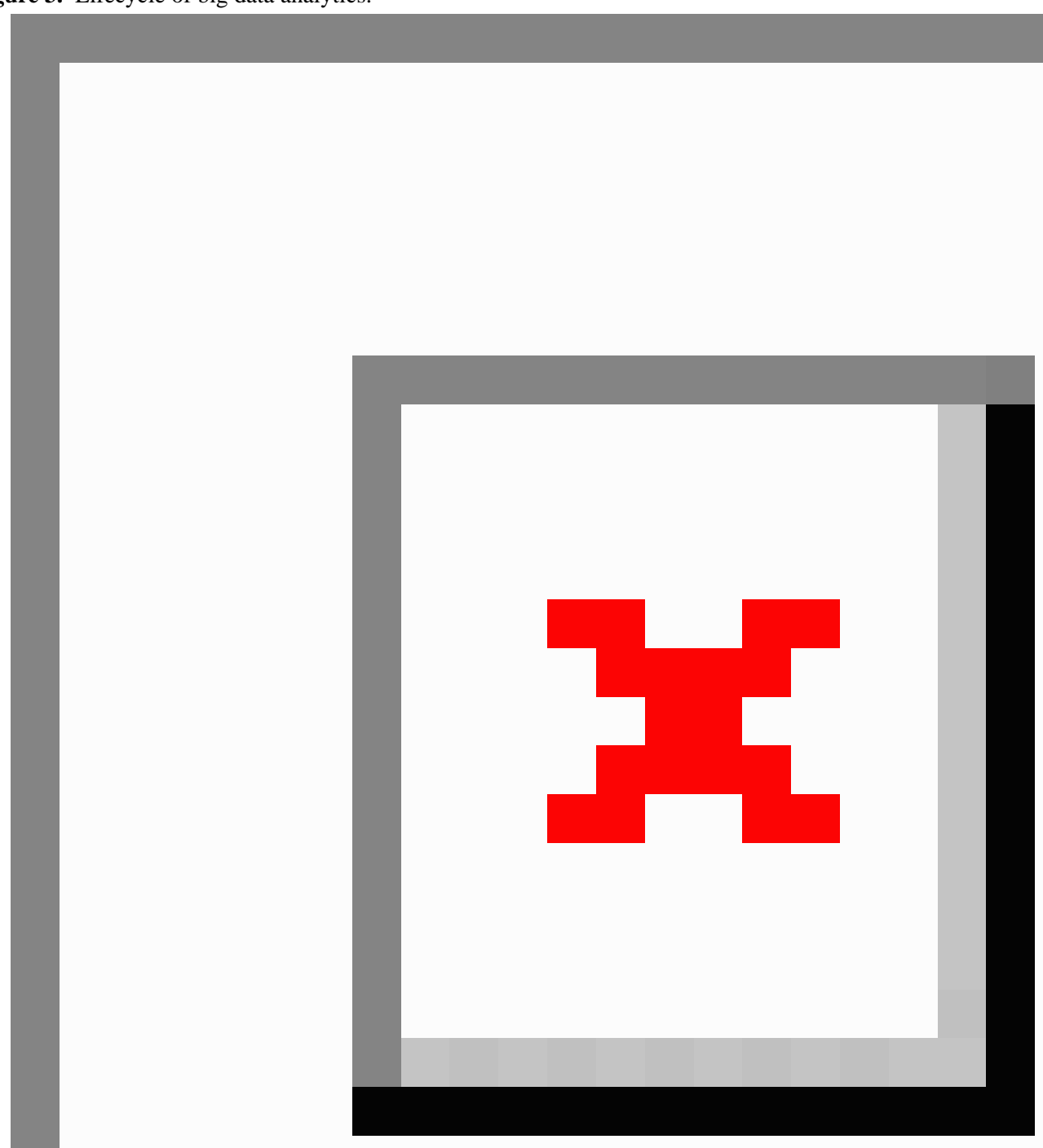

The prediction from health care data for public insights allows to actively improve public health and to react faster to a situation [83-91]. Using personal health care data requires, of course, a well-defined balance between the assurance of the privacy of personal health care data with respect to transparency, for example, toward insurance companies. Insights into genetical personal risk factors for chronic diseases should not lead to a situation where a person has disadvantages concerning the insurance status. Moreover, the monitoring of the public health situation has to be based on the health care data of individuals. Consequently, research projects have recently addressed the balance of personal health care data as a public good [92]. Figure 4 [92] shows the relationship between the 3 key stakeholders for defining the balance between personal health care data and the potential of these data as a public good. Companies could be health insurance providers, hospitals, pharmaceutical companies, and government organizations. 
Figure 4. Personal health care data ecosystem.

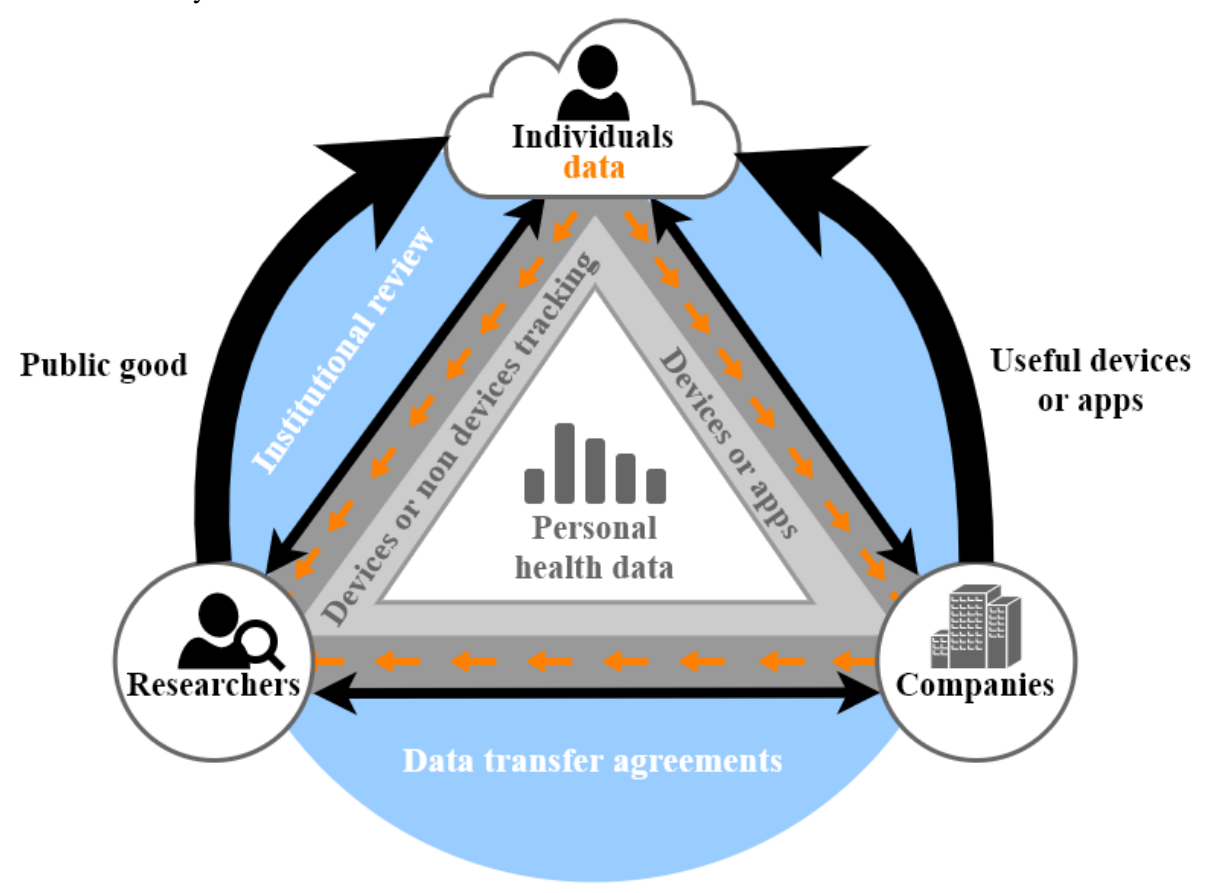

The diabetes mellitus crisis or the growth of cardiovascular problems caused by nutrition patterns and lifestyle behavior in many countries and regions of the world, changing patterns of Alzheimer and dementia, or microbiome research, and the abuse of antibiotics would benefit tremendously from personal health care data as a public good $[93,94]$. Bringing together the insights of large initiatives such as the Health Data Exploration Project and Computational Health Sciences [92,94] promises the key for future advancement in the area of private and personal health care data for the public good. Health care data analytics can help researchers and government officials for better prediction of chronic diseases, the development of effective therapeutic drugs, more accurate patient care, and the development of a nation-wide effective prevention plan.

Table 4 shows health data management systems presented in the taxonomy and evaluates them in terms of their adherence to the defined requirements. 
Table 4. Health data management systems in the literature vs the requirements.

\begin{tabular}{|c|c|c|c|c|c|c|c|c|c|c|}
\hline \multirow[t]{2}{*}{ System } & \multirow{2}{*}{$\begin{array}{l}\text { Medical } \\
\text { record data }\end{array}$} & \multirow[t]{2}{*}{ Real-time data } & \multicolumn{2}{|c|}{ Patient participation } & \multicolumn{3}{|l|}{ Sharing } & \multirow[t]{2}{*}{ Security } & \multirow[t]{2}{*}{ Privacy } & \multirow{2}{*}{$\begin{array}{l}\text { Public } \\
\text { insights }\end{array}$} \\
\hline & & & $\begin{array}{l}\text { Data ac- } \\
\text { cess }\end{array}$ & $\begin{array}{l}\text { Data in- } \\
\text { put }\end{array}$ & Degree 1 & Degree 2 & Degree 3 & & & \\
\hline Paper-based & $\begin{array}{l}\text { Allows } \\
\text { recording } \\
\text { of medical } \\
\text { data for } \\
\text { eventual } \\
\text { use }\end{array}$ & $\begin{array}{l}\text { Encounters } \\
\text { high delays }\end{array}$ & $\begin{array}{l}\text { Does not } \\
\text { allow pa- } \\
\text { tients to } \\
\text { track the } \\
\text { use of } \\
\text { their med- } \\
\text { ical data }\end{array}$ & $\begin{array}{l}\text { Does not } \\
\text { allow pa- } \\
\text { tients to } \\
\text { provide } \\
\text { their } \\
\text { health } \\
\text { condi- } \\
\text { tions }\end{array}$ & $\begin{array}{l}\text { Supports } \\
\text { data shar- } \\
\text { ing only } \\
\text { within the } \\
\text { same hos- } \\
\text { pital }\end{array}$ & $\begin{array}{l}\text { Allows } \\
\text { data shar- } \\
\text { ing with } \\
\text { the pa- } \\
\text { tient, pa- } \\
\text { tient's } \\
\text { friends, } \\
\text { and fami- } \\
\text { ly }\end{array}$ & $\begin{array}{l}\text { Does not al- } \\
\text { low data shar- } \\
\text { ing with the } \\
\text { patient, pa- } \\
\text { tient's friends, } \\
\text { and family }\end{array}$ & $\begin{array}{l}\text { Does not } \\
\text { provide } \\
\text { methods } \\
\text { against cyber- } \\
\text { security at- } \\
\text { tacks }\end{array}$ & $\begin{array}{l}\text { Does not } \\
\text { provide } \\
\text { methods } \\
\text { for pre- } \\
\text { serving a } \\
\text { patient's } \\
\text { privacy }\end{array}$ & $\begin{array}{l}\text { Does } \\
\text { not sup- } \\
\text { port pre- } \\
\text { diction }\end{array}$ \\
\hline $\begin{array}{l}\text { Computer- } \\
\text { based }\end{array}$ & $\begin{array}{l}\text { Allows } \\
\text { recording } \\
\text { of medical } \\
\text { data for } \\
\text { eventual } \\
\text { use }\end{array}$ & $\begin{array}{l}\text { Encounters } \\
\text { high delays }\end{array}$ & $\begin{array}{l}\text { Does not } \\
\text { allow pa- } \\
\text { tients to } \\
\text { track the } \\
\text { use of } \\
\text { their med- } \\
\text { ical data }\end{array}$ & $\begin{array}{l}\text { Does not } \\
\text { allow pa- } \\
\text { tients to } \\
\text { provide } \\
\text { their } \\
\text { health } \\
\text { condi- } \\
\text { tions }\end{array}$ & $\begin{array}{l}\text { Supports } \\
\text { data shar- } \\
\text { ing only } \\
\text { within the } \\
\text { same hos- } \\
\text { pital }\end{array}$ & $\begin{array}{l}\text { Allows } \\
\text { data shar- } \\
\text { ing with } \\
\text { the pa- } \\
\text { tient, pa- } \\
\text { tient's } \\
\text { friends, } \\
\text { and fami- } \\
\text { ly }\end{array}$ & $\begin{array}{l}\text { Allows data } \\
\text { sharing with } \\
\text { other medical } \\
\text { organizations } \\
\text { and govern- } \\
\text { ment }\end{array}$ & $\begin{array}{l}\text { Does not } \\
\text { provide } \\
\text { methods } \\
\text { against cyber- } \\
\text { security at- } \\
\text { tacks }\end{array}$ & $\begin{array}{l}\text { Does not } \\
\text { provide } \\
\text { methods } \\
\text { for pre- } \\
\text { serving a } \\
\text { patient's } \\
\text { privacy }\end{array}$ & $\begin{array}{l}\text { Does } \\
\text { not sup- } \\
\text { port pre- } \\
\text { diction }\end{array}$ \\
\hline $\begin{array}{l}\text { Client-serv- } \\
\text { er-based }\end{array}$ & $\begin{array}{l}\text { Allows } \\
\text { recording } \\
\text { of medical } \\
\text { data for } \\
\text { eventual } \\
\text { use }\end{array}$ & $\begin{array}{l}\text { Allows data } \\
\text { retrieval in re- } \\
\text { al time }\end{array}$ & $\begin{array}{l}\text { Allows } \\
\text { patients } \\
\text { to access } \\
\text { and moni- } \\
\text { tor their } \\
\text { medical } \\
\text { data }\end{array}$ & $\begin{array}{l}\text { Does not } \\
\text { allow pa- } \\
\text { tients to } \\
\text { provide } \\
\text { their } \\
\text { health } \\
\text { condi- } \\
\text { tions }\end{array}$ & $\begin{array}{l}\text { Supports } \\
\text { data shar- } \\
\text { ing only } \\
\text { within the } \\
\text { same hos- } \\
\text { pital }\end{array}$ & $\begin{array}{l}\text { Allows } \\
\text { data shar- } \\
\text { ing with } \\
\text { the pa- } \\
\text { tient, pa- } \\
\text { tient's } \\
\text { friends, } \\
\text { and fami- } \\
\text { ly }\end{array}$ & $\begin{array}{l}\text { Allows data } \\
\text { sharing with } \\
\text { other medical } \\
\text { organizations } \\
\text { and govern- } \\
\text { ment }\end{array}$ & $\begin{array}{l}\text { Does not } \\
\text { provide } \\
\text { methods } \\
\text { against cyber- } \\
\text { security at- } \\
\text { tacks }\end{array}$ & $\begin{array}{l}\text { Does not } \\
\text { provide } \\
\text { methods } \\
\text { for pre- } \\
\text { serving a } \\
\text { patient's } \\
\text { privacy }\end{array}$ & $\begin{array}{l}\text { Does } \\
\text { not sup- } \\
\text { port pre- } \\
\text { diction }\end{array}$ \\
\hline Cloud-based & $\begin{array}{l}\text { Allows } \\
\text { recording } \\
\text { of medical } \\
\text { data for } \\
\text { eventual } \\
\text { use }\end{array}$ & $\begin{array}{l}\text { Allows data } \\
\text { retrieval in re- } \\
\text { al time }\end{array}$ & $\begin{array}{l}\text { Allows } \\
\text { patients } \\
\text { to access } \\
\text { and moni- } \\
\text { tor their } \\
\text { medical } \\
\text { data }\end{array}$ & $\begin{array}{l}\text { Does not } \\
\text { allow pa- } \\
\text { tients to } \\
\text { provide } \\
\text { their } \\
\text { health } \\
\text { condi- } \\
\text { tions }\end{array}$ & $\begin{array}{l}\text { Supports } \\
\text { data shar- } \\
\text { ing only } \\
\text { within the } \\
\text { same hos- } \\
\text { pital }\end{array}$ & $\begin{array}{l}\text { Allows } \\
\text { data shar- } \\
\text { ing with } \\
\text { the pa- } \\
\text { tient, pa- } \\
\text { tient's } \\
\text { friends, } \\
\text { and fami- } \\
\text { ly }\end{array}$ & $\begin{array}{l}\text { Allows data } \\
\text { sharing with } \\
\text { other medical } \\
\text { organizations } \\
\text { and govern- } \\
\text { ment }\end{array}$ & $\begin{array}{l}\text { Does not } \\
\text { provide } \\
\text { methods } \\
\text { against cyber- } \\
\text { security at- } \\
\text { tacks }\end{array}$ & $\begin{array}{l}\text { Does not } \\
\text { reveal a } \\
\text { patient's } \\
\text { identity }\end{array}$ & $\begin{array}{l}\text { Does } \\
\text { not sup- } \\
\text { port pre- } \\
\text { diction }\end{array}$ \\
\hline IoT $^{\mathrm{a}}$-based & $\begin{array}{l}\text { Allows } \\
\text { recording } \\
\text { of medical } \\
\text { data for } \\
\text { eventual } \\
\text { use }\end{array}$ & $\begin{array}{l}\text { Allows data } \\
\text { retrieval in re- } \\
\text { al time }\end{array}$ & $\begin{array}{l}\text { Allows } \\
\text { patients } \\
\text { to access } \\
\text { and moni- } \\
\text { tor their } \\
\text { medical } \\
\text { data }\end{array}$ & $\begin{array}{l}\text { Allows } \\
\text { patients } \\
\text { to pro- } \\
\text { vide } \\
\text { health } \\
\text { condi- } \\
\text { tions }\end{array}$ & $\begin{array}{l}\text { Supports } \\
\text { data shar- } \\
\text { ing only } \\
\text { within the } \\
\text { same hos- } \\
\text { pital }\end{array}$ & $\begin{array}{l}\text { Allows } \\
\text { data shar- } \\
\text { ing with } \\
\text { the pa- } \\
\text { tient, pa- } \\
\text { tient's } \\
\text { friends, } \\
\text { and fami- } \\
\text { ly }\end{array}$ & $\begin{array}{l}\text { Allows data } \\
\text { sharing with } \\
\text { other medical } \\
\text { organizations } \\
\text { and govern- } \\
\text { ment }\end{array}$ & $\begin{array}{l}\text { Does not } \\
\text { provide } \\
\text { methods } \\
\text { against cyber- } \\
\text { security at- } \\
\text { tacks }\end{array}$ & $\begin{array}{l}\text { Does not } \\
\text { provide } \\
\text { methods } \\
\text { for pre- } \\
\text { serving a } \\
\text { patient's } \\
\text { privacy }\end{array}$ & $\begin{array}{l}\text { Pro- } \\
\text { vides } \\
\text { methods } \\
\text { for the } \\
\text { predic- } \\
\text { tion of } \\
\text { health } \\
\text { condi- } \\
\text { tions }\end{array}$ \\
\hline $\begin{array}{l}\text { Big data analyt- } \\
\text { ics }\end{array}$ & $\begin{array}{l}\text { Allows } \\
\text { recording } \\
\text { of medical } \\
\text { data for } \\
\text { eventual } \\
\text { use }\end{array}$ & $\begin{array}{l}\text { Allows data } \\
\text { retrieval in re- } \\
\text { al time }\end{array}$ & $\begin{array}{l}\text { Allows } \\
\text { patients } \\
\text { to access } \\
\text { and moni- } \\
\text { tor their } \\
\text { medical } \\
\text { data }\end{array}$ & $\begin{array}{l}\text { Allows } \\
\text { patients } \\
\text { to pro- } \\
\text { vide } \\
\text { health } \\
\text { condi- } \\
\text { tions }\end{array}$ & $\begin{array}{l}\text { Supports } \\
\text { data shar- } \\
\text { ing only } \\
\text { within the } \\
\text { same hos- } \\
\text { pital }\end{array}$ & $\begin{array}{l}\text { Allows } \\
\text { data shar- } \\
\text { ing with } \\
\text { the pa- } \\
\text { tient, pa- } \\
\text { tient's } \\
\text { friends, } \\
\text { and fami- } \\
\text { ly }\end{array}$ & $\begin{array}{l}\text { Allows data } \\
\text { sharing with } \\
\text { other medical } \\
\text { organizations } \\
\text { and govern- } \\
\text { ment }\end{array}$ & $\begin{array}{l}\text { Does not } \\
\text { provide } \\
\text { methods } \\
\text { against cyber- } \\
\text { security at- } \\
\text { tacks }\end{array}$ & $\begin{array}{l}\text { Does not } \\
\text { reveal a } \\
\text { patient's } \\
\text { identity }\end{array}$ & $\begin{array}{l}\text { Pro- } \\
\text { vides } \\
\text { methods } \\
\text { for the } \\
\text { predic- } \\
\text { tion of } \\
\text { health } \\
\text { condi- } \\
\text { tions }\end{array}$ \\
\hline
\end{tabular}




\begin{tabular}{|c|c|c|c|c|c|c|c|c|c|c|}
\hline \multirow[t]{2}{*}{ System } & \multirow{2}{*}{$\begin{array}{l}\text { Medical } \\
\text { record data }\end{array}$} & \multirow[t]{2}{*}{ Real-time data } & \multicolumn{2}{|c|}{ Patient participation } & \multicolumn{3}{|l|}{ Sharing } & \multirow[t]{2}{*}{ Security } & \multirow[t]{2}{*}{ Privacy } & \multirow{2}{*}{$\begin{array}{l}\text { Public } \\
\text { insights }\end{array}$} \\
\hline & & & $\begin{array}{l}\text { Data ac- } \\
\text { cess }\end{array}$ & $\begin{array}{l}\text { Data in- } \\
\text { put }\end{array}$ & Degree 1 & Degree 2 & Degree 3 & & & \\
\hline $\begin{array}{l}\text { Blockchain- } \\
\text { based }\end{array}$ & $\begin{array}{l}\text { Allows } \\
\text { recording } \\
\text { of medical } \\
\text { data for } \\
\text { eventual } \\
\text { use }\end{array}$ & $\begin{array}{l}\text { Allows data } \\
\text { retrieval in re- } \\
\text { al time }\end{array}$ & $\begin{array}{l}\text { Allows } \\
\text { patients } \\
\text { to access } \\
\text { and moni- } \\
\text { tor their } \\
\text { medical } \\
\text { data }\end{array}$ & $\begin{array}{l}\text { Allows } \\
\text { patients } \\
\text { to pro- } \\
\text { vide } \\
\text { health } \\
\text { condi- } \\
\text { tions }\end{array}$ & $\begin{array}{l}\text { Supports } \\
\text { data shar- } \\
\text { ing only } \\
\text { within the } \\
\text { same hos- } \\
\text { pital }\end{array}$ & $\begin{array}{l}\text { Allows } \\
\text { data shar- } \\
\text { ing with } \\
\text { the pa- } \\
\text { tient, pa- } \\
\text { tient's } \\
\text { friends, } \\
\text { and fami- } \\
\text { ly }\end{array}$ & $\begin{array}{l}\text { Allows data } \\
\text { sharing with } \\
\text { other medical } \\
\text { organizations } \\
\text { and govern- } \\
\text { ment }\end{array}$ & $\begin{array}{l}\text { Ensures the } \\
\text { protection of } \\
\text { medical data } \\
\text { against cyber- } \\
\text { security at- } \\
\text { tacks }\end{array}$ & $\begin{array}{l}\text { Does not } \\
\text { reveal a } \\
\text { patient's } \\
\text { identity }\end{array}$ & $\begin{array}{l}\text { Pro- } \\
\text { vides } \\
\text { methods } \\
\text { for the } \\
\text { predic- } \\
\text { tion of } \\
\text { health } \\
\text { condi- } \\
\text { tions }\end{array}$ \\
\hline
\end{tabular}

${ }^{\mathrm{a}}$ IoT: Internet of Things.

\section{Discussion}

\section{Principal Findings}

This study revealed that there is a need for a secure and efficient health data management system that will allow physicians and patients to update decentralized medical records and to analyze the medical data for supporting more precise diagnoses, prognoses, biomedical research, and public insights. The early form of health data management using the manual recording of a patient's diagnosis and treatment on sheets of paper was introduced almost a century ago. Later, with the advancement in technology, health data management systems evolved to web, cloud, IoT, big data analytics, and blockchain-based systems. The definition of medical records has reformed alongside this temporal evolution of the system. The requirements for a health data management system extracted from these definitions are medical record data, real-time data, patient participation, sharing, security, privacy, and public insights. The paper-based health data management system fulfills the requirements of medical record data and sharing. However, paper charts are prone to misplacement, occupy large physical space, and involve a time-consuming and expensive data sharing process. Over time, the paper charts were replaced by electronic records in the computer-based system with the same requirements.

To achieve the requirement of real-time data access in addition to medical record data and sharing, a client-server-based health data management system was introduced. This system allows patients and health care providers to access medical data over the internet using a mobile device or a desktop computer. However, it suffers from the issues of single point of failure, data fragmentation, system vulnerability, low scalability, and high data security and patient privacy risks. To minimize the infrastructural cost and to address the issue of data fragmentation, the medical organizations and health care providers transitioned to a cloud-based system. The cloud service provider ensures the requirement of privacy of patient identity, but the security of the data is not ensured in addition to the issue of a single point of failure.

The requirement of patient participation to feed their medical data and lifestyle conditions for better prognosis and diagnosis was achieved with the introduction of the IoT-based management system. However, with the increasing number of data breaches and hacking of the medical sensors and devices, there prevails a constant threat to the security of data and privacy of a patient's identity. With the advancement in big data analytics, increasing amount of health care data are being studied to gain insights for better prognosis and diagnosis of diseases. However, the privacy of a patient's identity still remains a concern.

The blockchain technology, which recently attracted the attention of industries, shows potential in the field of health care. A blockchain-based health data management system satisfies all the requirements needed for better patient care. However, it consumes a high amount of energy $[95,96]$ and has low throughput [39]. There are increasing research efforts to solve these issues. For instance, to address the problem of energy consumption, Milutinovic et al [97] proposed the proof of luck consensus mechanism that ensures energy-efficient and low-latency transaction validation. Ismail et al [98] and Dorri et al [99] proposed scalable blockchain architectures for health care that use a clustering approach to increase transactions throughput.

The main requirements of a health care data management system are security and privacy, especially with the increasing number of data breaching and hacking attacks. Furthermore, the adoption of patient participation to feed health data to a health system is increasing with the introduction of disruptive technologies, such as the IoT and big data analytics. Big data analytics requires the sharing of medical information among hospitals to get insights and predictive analysis from the data. This paves the way toward a health data management system as a support to physicians and medical professionals for better diagnosis and prognosis of chronic diseases. In addition, such a system allows to derive public insights from data to develop a nation-wide prevention plan for certain diseases. The traceability feature of the blockchain ensures that the data used for developing the predictive models is accurate, leading to a precise prognosis, diagnosis, and decision support system. Consequently, we suggest an integrated blockchain-, IoT- and big data-based health data management system to ensure the requirements of smart health care: real-time access to data by physicians and patients, health data input from patients through medical sensors and lifestyle, security, privacy, and public insights. This integrated health management system should be scalable and energy-efficient, presenting new research challenges in the research era of a smart health data management system. 


\section{Conclusions}

The objective of this paper was to highlight the requirements of a health data management system for biomedical care and research. In summary, it discussed the temporal evolution of health data management systems from paper charts to blockchain-based systems, along with the reformation of the definition of what we call EHRs today. The system should satisfy the requirements of medical record data, real-time access, patient participation, data sharing, data security, patient identity privacy, and public insights. The incorporation of big data analytics aids in better prognosis and diagnosis of the diseases and the prediction of risk for the development of chronic diseases.

\section{Acknowledgments}

This work was supported by the Emirates Center for Energy and Environment Research of the United Arab Emirates University under grant 31R101. The authors would like to thank the anonymous reviewers for their valuable comments, which helped them improve the content, quality, and presentation of this paper.

\section{Conflicts of Interest}

None declared.

\section{References}

1. Healthcare Information and Management Systems Society. What Are Electronic Health Records (EHRs)? URL: https:/ /www.himss.org/electronic-health-records [accessed 2020-02-13]

2. King J, Patel V, Jamoom EW, Furukawa MF. Clinical benefits of electronic health record use: national findings. Health Serv Res 2014 Feb;49(1 Pt 2):392-404 [FREE Full text] [doi: 10.1111/1475-6773.12135] [Medline: 24359580]

3. Raghupathi W, Raghupathi V. Big data analytics in healthcare: promise and potential. Health Inf Sci Syst 2014;2(1):3 [FREE Full text] [doi: 10.1186/2047-2501-2-3] [Medline: 25825667]

4. Kuo MH, Sahama T, Kushniruk AW, Borycki EM, Grunwell DK. Health big data analytics: current perspectives, challenges and potential solutions. Int J Big Data Intell 2014;1(1/2):114. [doi: 10.1504/ijbdi.2014.063835]

5. Jamal A, McKenzie K, Clark M. The impact of health information technology on the quality of medical and health care: a systematic review. Health Inf Manag 2009;38(3):26-37. [doi: 10.1177/183335830903800305] [Medline: 19875852]

6. Van De Belt TH, Engelen LJ, Berben SA, Schoonhoven L. Definition of health 2.0 and medicine 2.0: a systematic review. J Med Internet Res 2010 Jun 11;12(2):e18 [FREE Full text] [doi: 10.2196/jmir.1350] [Medline: 20542857]

7. Oh H, Rizo C, Enkin M, Jadad A. What is ehealth (3): a systematic review of published definitions. J Med Internet Res 2005 Feb 24;7(1):e1 [FREE Full text] [doi: 10.2196/jmir.7.1.e1] [Medline: 15829471]

8. Cunningham SG, Wake DJ, Waller A, Morris AD. Definitions of eHealth. In: Gaddi A, Manca M, editors. eHealth, Care and Quality of Life. New York, USA: Springer; 2013:15-30.

9. Silva BM, Rodrigues JJ, de la Torre Díez I, López-Coronado M, Saleem K. Mobile-health: a review of current state in 2015. J Biomed Inform 2015 Aug;56:265-272 [FREE Full text] [doi: 10.1016/j.jbi.2015.06.003] [Medline: 26071682]

10. Siegler EL. The evolving medical record. Ann Intern Med 2010 Nov 16;153(10):671-677. [doi: 10.7326/0003-4819-153-10-201011160-00012] [Medline: 21079225]

11. Thomas E, John M, Charles R, Society of the New York Hospital. An Account of the New York Hospital. Medical Center Archives 1811.

12. Sayles NB, Gordon LL. Health Information Management Technology: An Applied Approach. Chicago, USA: American Health Information Management Association; 2013.

13. American Health Information Management Association. AHIMA History URL: http://bok.ahima.org/doc?oid=58133\#. $\underline{\text { XnNMSIgzbIU }}$ [accessed 2020-02-13]

14. Weed LL. Medical records that guide and teach. N Engl J Med 1968 Mar 14;278(11):593-600. [doi: 10.1056/NEJM196803142781105] [Medline: 5637758]

15. Centers for Medicare \& Medicaid Services. 1965. CMS' Program History URL: https://www.cms.gov/About-CMS/ Agency-information/History/ [accessed 2020-02-13]

16. Tripathi M. EHR evolution: policy and legislation forces changing the EHR. J AHIMA 2012 Oct;83(10):24-9; quiz 30. [Medline: 23061349]

17. Gardner RM, Pryor T, Warner HR. The HELP hospital information system: update 1998. Int J Med Inform 1999 Jun;54(3):169-182. [doi: 10.1016/s1386-5056(99)00013-1] [Medline: 10405877]

18. Amatayakul MK. Electronic Health Records: A Practical Guide for Professionals and Organizations. Chicago, USA: American Health Information Management; 2004.

19. IHS Markit. 1980. Master Patient Index (MPI) URL: https://www.ihs.gov/hie/masterpatientindex/ [accessed 2020-02-13]

20. Hammond WE. Health level 7: an application standard for electronic medical data exchange. Top Health Rec Manage 1991 Jun;11(4):59-66. [Medline: 10112038]

21. Dick RS, Steen EB, Detmer DE. The Computer-based Patient Record: An Essential Technology for Health Care. Washington, DC: National Academies Press; 1997. 
22. United States Department of Health and Human Services. Summary of the HIPAA Security Rule URL: https://www.hhs.gov/ hipaa/for-professionals/security/laws-regulations/index.html [accessed 2020-02-13]

23. John M. From Telehealth to E-health: The Unstoppable Rise of E-health. Australia: Department of Communications, Information Technology and the Arts; 1999.

24. Laxminarayan S, Istepanian R. Unwired e-med: the next generation of wireless and internet telemedicine systems. IEEE Trans Inf Technol Biomed 2000 Sep;4(3):189-193. [doi: 10.1109/titb.2000.5956074] [Medline: 11026588]

25. Eysenbach G. What is e-health? J Med Internet Res 2001;3(2):E20 [FREE Full text] [doi: 10.2196/jmir.3.2.e20] [Medline: 11720962]

26. Intille SS. Ubiquitous computing technology for just-in-time motivation of behavior change. Stud Health Technol Inform 2004;107(Pt 2):1434-1437. [doi: 10.3233/978-1-60750-949-3-1434] [Medline: 15361052]

27. Kim MI, Johnson KB. Personal health records: evaluation of functionality and utility. J Am Med Inform Assoc 2002;9(2):171-180 [FREE Full text] [doi: 10.1197/jamia.m0978] [Medline: 11861632]

28. Gillies J, Holt A. Anxious about electronic health records? No need to be. N Z Med J 2003 Sep 26;116(1182):U604. [Medline: 14581956]

29. Holahan J, Blumberg L. Massachusetts health care reform: a look at the issues. Health Aff (Millwood) 2006;25(6):w432-w443. [doi: 10.1377/hlthaff.25.w432] [Medline: 16973652]

30. Centers for Medicare \& Medicaid Services. 2006. Accountable Care Organizations (ACOs) URL: https://www.cms.gov/ Medicare/Medicare-Fee-for-Service-Payment/ACO [accessed 2020-02-13]

31. US Department of Justice. 2016. Fact Sheet: The Health Care Fraud and Abuse Control Program Protects Conusmers and Taxpayers by Combating Health Care Fraud URL: https://www.justice.gov/opa/pr/ fact-sheet-health-care-fraud-and-abuse-control-program-protects-conusmers-and-taxpayers [accessed 2020-02-13]

32. HealthCare. 2010. Patient Protection and Affordable Care Act URL: https://www.healthcare.gov/glossary/ patient-protection-and-affordable-care-act/ [accessed 2020-02-13]

33. Sokol DK, Hettige S. Poor handwriting remains a significant problem in medicine. J R Soc Med 2006 Dec;99(12):645-646 [FREE Full text] [doi: 10.1258/jrsm.99.12.645] [Medline: 17139073]

34. Leonidas LL. Opinion - Inquirer.net. 2014. Death by Bad Handwriting URL: https://opinion.inquirer.net/79623/ death-by-bad-handwriting [accessed 2020-02-13]

35. Charatan F. Family compensated for death after illegible prescription. Br Med J 1999 Dec 4;319(7223):1456 [FREE Full text] [doi: 10.1136/bmj.319.7223.1456] [Medline: 10582922]

36. Davis J. Healthcare IT News. 2017. eClinicalWorks Sued for Nearly \$1 Billion for Inaccurate Medical Records URL: https://www.healthcareitnews.com/news/eclinicalworks-sued-nearly-1-billion-inaccurate-medical-records [accessed 2020-02-13]

37. Amazon Web Services. 2018. United States District Court Northern District of Illinois URL: https://s3.amazonaws.com/ assets.fiercemarkets.net/public/004-Healthcare/external_Q12018/SurfsidevAllscripts.pdf [accessed 2020-02-13]

38. The Guardian. 2017. Bitcoin Mining Consumes More Electricity a Year Than Ireland URL: https://www.theguardian.com/ technology/2017/nov/27/bitcoin-mining-consumes-electricity-ireland [accessed 2020-02-13]

39. Scherer M. UMEA University. 2017. Performance and Scalability of Blockchain Networks and Smart Contracts URL: https://umu.diva-portal.org/smash/get/diva2:1111497/FULLTEXT01.pdf [accessed 2020-03-24]

40. Miller C. The electronic medical record: a definition and discussion. Top Health Inf Manage 1993 Feb;13(3):20-29. [Medline: 10124869]

41. Cameron S, Turtle-Song I. Learning to write case notes using the SOAP format. J Couns Dev 2002;80(3):286-292. [doi: 10.1002/j.1556-6678.2002.tb00193.x]

42. Markle: Advancing America's Future. 2003. Personal Health Working Group Final Report URL: https://www.markle.org/ publications/1429-personal-health-working-group-final-report [accessed 2020-02-13]

43. Handler R, Holtmeier R, Metzger J, Overhage M, Taylor S, Underwood C. Healthcare Information and Management Systems Society. 2003. HIMSS Electronic Health Record Definitional Model URL: http://www.providersedge.com/ehdocs/ ehr articles/HIMSS EMR Definition Model v1-0.pdf [accessed 2020-02-13]

44. AHIMA e-HIM Personal Health Record Work Group. Defining the Personal Health Record. J AHIMA 2005 Jun 11;156(24):786-786. [doi: 10.1136/vr.156.24.786-a]

45. Böcking W, Trojanus D. Health Data Management. In: Kirch W, editor. Encyclopedia of Public Health. New York, USA: Springer; 2008.

46. Kohane IS, Greenspun P, Fackler J, Cimino C, Szolovits P. Building national electronic medical record systems via the World Wide Web. J Am Med Inform Assoc 1996;3(3):191-207 [FREE Full text] [doi: 10.1136/jamia.1996.96310633] [Medline: $\underline{8723610}$ ]

47. Rind DM, Kohane IS, Szolovits P, Safran C, Chueh HC, Barnett GO. Maintaining the confidentiality of medical records shared over the internet and the world wide web. Ann Intern Med 1997 Jul 15;127(2):138-141. [doi: 10.7326/0003-4819-127-2-199707150-00008] [Medline: 9230004]

48. Schoenberg R, Safran C. Internet based repository of medical records that retains patient confidentiality. Br Med J 2000 Nov 11;321(7270):1199-1203 [FREE Full text] [doi: 10.1136/bmj.321.7270.1199] [Medline: 11073513 ] 
49. Uckert F, Görz M, Ataian M, Prokosch HU. Akteonline-an electronic healthcare record as a medium for information and communication. Stud Health Technol Inform 2002;90:293-297. [Medline: 15460705]

50. Grant RW, Wald JS, Poon EG, Schnipper JL, Gandhi TK, Volk LA, et al. Design and implementation of a web-based patient portal linked to an ambulatory care electronic health record: patient gateway for diabetes collaborative care. Diabetes Technol Ther 2006 Oct;8(5):576-586 [FREE Full text] [doi: 10.1089/dia.2006.8.576] [Medline: 17037972]

51. Ross SE, Moore LA, Earnest MA, Wittevrongel L, Lin C. Providing a web-based online medical record with electronic communication capabilities to patients with congestive heart failure: randomized trial. J Med Internet Res 2004 May 14;6(2):e12 [FREE Full text] [doi: 10.2196/jmir.6.2.e12] [Medline: 15249261$]$

52. Marceglia S, Bonacina S, Braidotti A, Nardelli M, Pinciroli F. Towards a web-based system for family health record. AMIA Annu Symp Proc 2006:1023 [FREE Full text] [Medline: 17238642]

53. Laplante PA, Kassab M, Laplante NL, Voas JM. Building caring healthcare systems in the internet of things. IEEE Syst J 2018;12(3):- [FREE Full text] [doi: 10.1109/JSYST.2017.2662602] [Medline: 31080541]

54. Wu F, Wu T, Yuce M. An internet-of-things (IoT) network system for connected safety and health monitoring applications. Sensors (Basel) 2018 Dec 21;19(1):E21 [FREE Full text] [doi: 10.3390/s19010021] [Medline: 30577646]

55. Meinert E, van Velthoven M, Brindley D, Alturkistani A, Foley K, Rees S, et al. The internet of things in health care in Oxford: protocol for proof-of-concept projects. JMIR Res Protoc 2018 Dec 4;7(12):e12077 [FREE Full text] [doi: 10.2196/12077] [Medline: $\underline{30514695]}$

56. Mavrogiorgou A, Kiourtis A, Perakis K, Pitsios S, Kyriazis D. IoT in healthcare: achieving interoperability of high-quality data acquired by IoT medical devices. Sensors (Basel) 2019 Apr 27;19(9):1-24 [FREE Full text] [doi: 10.3390/s19091978] [Medline: 31035612$]$

57. Valluru D, Jeya IJ. IoT with cloud based lung cancer diagnosis model using optimal support vector machine. Health Care Manag Sci 2019 Jul 20:- epub ahead of print. [doi: 10.1007/s10729-019-09489-x] [Medline: 31327114]

58. Ramirez Lopez LJ, Puerta Aponte G, Rodriguez Garcia A. Internet of things applied in healthcare based on open hardware with low-energy consumption. Healthc Inform Res 2019 Jul;25(3):230-235 [FREE Full text] [doi: 10.4258/hir.2019.25.3.230] [Medline: 31406615]

59. Qu Y, Ming X, Qiu S, Zheng M, Hou Z. An integrative framework for online prognostic and health management using internet of things and convolutional neural network. Sensors (Basel) 2019 May 21;19(10):1 [FREE Full text] [doi: 10.3390/s19102338] [Medline: 31117213]

60. Rau H, Wu Y, Chu C, Wang F, Hsu M, Chang C, et al. Importance-performance analysis of personal health records in Taiwan: a web-based survey. J Med Internet Res 2017 Apr 27;19(4):e131 [FREE Full text] [doi: 10.2196/jmir.7065] [Medline: 28450273]

61. Bahga A, Madisetti VK. A cloud-based approach for interoperable electronic health records (EHRs). IEEE J Biomed Health Inform 2013 Sep;17(5):894-906. [doi: 10.1109/JBHI.2013.2257818] [Medline: 25055368]

62. Fernández-Cardeñosa G, de la Torre-Díez I, López-Coronado M, Rodrigues JJ. Analysis of cloud-based solutions on EHRs systems in different scenarios. J Med Syst 2012 Dec;36(6):3777-3782. [doi: 10.1007/s10916-012-9850-2] [Medline: 22492177]

63. Zangara G, Corso PP, Cangemi F, Millonzi F, Collova F, Scarlatella A. A cloud based architecture to support electronic health record. Stud Health Technol Inform 2014;207:380-389. [doi: 10.3233/978-1-61499-474-9-380] [Medline: 25488244]

64. Schulz S, Stegwee R, Chronaki C. Standards in healthcare data. In: Kubben P, Dumontier M, Dekker A, editors. Standards in Healthcare Data. New York, USA: Springer; 2019:19-36.

65. MRC Cognition and Brain Sciences Unit. The Analyze Data Format URL: http://imaging.mrc-cbu.cam.ac.uk/imaging/ FormatAnalyze [accessed 2020-02-13]

66. NIfTI: Neuroimaging Informatics Technology Initiative. URL: https://nifti.nimh.nih.gov/ [accessed 2020-02-13]

67. Vincent RD, Neelin P, Khalili-Mahani N, Janke AL, Fonov VS, Robbins SM, et al. MINC 2.0: a flexible format for multi-modal images. Front Neuroinform 2016;10:35 [FREE Full text] [doi: 10.3389/fninf.2016.00035] [Medline: 27563289]

68. Digital Imaging and Communications in Medicine. URL: https://www.dicomstandard.org/ [accessed 2020-02-13]

69. Wen H, Chang W, Hsu M, Ho C, Chu C. An assessment of the interoperability of electronic health record exchanges among hospitals and clinics in Taiwan. JMIR Med Inform 2019 Mar 28;7(1):e12630 [FREE Full text] [doi: 10.2196/12630] [Medline: $\underline{30920376]}$

70. Davis J. HealthITSecurity. 2019. 15 Million Patient Records Breached in 2018; Hacking, Phishing Surges URL: https:/ /healthitsecurity.com/news/15-million-patient-records-breached-in-2018-hacking-phishing-surges [accessed 2020-02-13]

71. Business Wire. New Intel Security Cloud Report Reveals IT Departments Find It Hard to Keep the Cloud Safe URL: https:/ /www.businesswire.com/news/home/20170212005011/en/ [accessed 2020-02-13]

72. Zorz Z. Help Net Security - Information Security News. 2019. Healthcare's Blind spot: Unmanaged IoT and Medical Devices URL: https://www.helpnetsecurity.com/2019/07/22/healthcare-iot/ [accessed 2020-02-13]

73. Nakamoto S. Bitcoin: A Peer-to-Peer Electronic Cash System. New York, USA: BN Publishing; 2008.

74. Ismail L, Heba H, AlShamsi M, AlHammadi M, AlDhanhani N. Towards a Blockchain Deployment at UAE University: Performance Evaluation and Blockchain Taxonomy. In: Proceedings of the 2019 International Conference on Blockchain Technology. 2019 Presented at: ICBCT'19; March 15-18, 2019; Hawaii, USA p. 30-38. [doi: 10.1145/3320154.3320156] 
75. Azaria A, Ekblaw A, Vieira T, Lippman A. MedRec: Using Blockchain for Medical Data Access and Permission Management. In: Proceedings of the 2nd International Conference on Open and Big Data. 2016 Presented at: OBD'16; August 22-24, 2016; Vienna, Austria. [doi: 10.1109/obd.2016.11]

76. Li H, Zhu L, Shen M, Gao F, Tao X, Liu S. Blockchain-based data preservation system for medical data. J Med Syst 2018 Jun 28;42(8):141. [doi: 10.1007/s10916-018-0997-3] [Medline: 29956058]

77. Dagher GG, Mohler J, Milojkovic M, Marella PB. Ancile: privacy-preserving framework for access control and interoperability of electronic health records using blockchain technology. Sustain Cities Soc 2018 May;39:283-297. [doi: 10.1016/j.scs.2018.02.014]

78. Fan K, Wang S, Ren Y, Li H, Yang Y. MedBlock: efficient and secure medical data sharing via blockchain. J Med Syst 2018 Jun 21;42(8):136. [doi: 10.1007/s10916-018-0993-7] [Medline: 29931655]

79. Yue X, Wang H, Jin D, Li M, Jiang W. Healthcare data gateways: found healthcare intelligence on blockchain with novel privacy risk control. J Med Syst 2016 Oct;40(10):218. [doi: 10.1007/s10916-016-0574-6] [Medline: 27565509]

80. Dey T, Jaiswal S, SunderKrishnan S, Katre N. HealthSense: A Medical Use Case of Internet of Things and Blockchain. In: Proceedings of the International Conference on Intelligent Sustainable Systems. 2017 Presented at: ICISS'17; December 7-8, 2017; Palladam, India. [doi: 10.1109/iss1.2017.8389459]

81. Uddin MA, Stranieri A, Gondal I, Balasubramanian V. Continuous patient monitoring with a patient centric agent: a block architecture. IEEE Access 2018;6:32700-32726. [doi: 10.1109/access.2018.2846779]

82. Evariant: Healthcare's Only Patient for Life Platform. What is Healthcare Data Management and Why is it Important? URL: https://www.evariant.com/faq/why-is-healthcare-data-management-important [accessed 2020-02-13]

83. Bedi G, Carrillo F, Cecchi GA, Slezak DF, Sigman M, Mota NB, et al. Automated analysis of free speech predicts psychosis onset in high-risk youths. NPJ Schizophr 2015 Aug 26;1(1):15030-15037 [FREE Full text] [doi: 10.1038/npjschz.2015.30] [Medline: 27336038]

84. Yu K, Zhang C, Berry GJ, Altman RB, Ré C, Rubin DL, et al. Predicting non-small cell lung cancer prognosis by fully automated microscopic pathology image features. Nat Commun 2016 Aug 16;7:12474 [FREE Full text] [doi: 10.1038/ncomms12474] [Medline: 27527408]

85. Cruz-Roa A, Gilmore H, Basavanhally A, Feldman M, Ganesan S, Shih NN, et al. Accurate and reproducible invasive breast cancer detection in whole-slide images: a deep learning approach for quantifying tumor extent. Sci Rep 2017 Apr 18;7:46450 [FREE Full text] [doi: 10.1038/srep46450] [Medline: 28418027]

86. Liu Y, Gadepalli K, Norouzi M, Dahl GE, Kohlberger T, Boyko A, et al. arXiv. 2017. Detecting Cancer Metastases on Gigapixel Pathology Images URL: https://arxiv.org/abs/1703.02442 [accessed 2020-03-24]

87. Richter AN, Khoshgoftaar TM. Efficient learning from big data for cancer risk modeling: a case study with melanoma. Comput Biol Med 2019 Jul;110:29-39. [doi: 10.1016/j.compbiomed.2019.04.039] [Medline: 31112896]

88. Narula S, Shameer K, Salem Omar AM, Dudley JT, Sengupta PP. Machine-Learning Algorithms to Automate Morphological and FunctionaMachine-learning algorithms to automate morphological and functional assessments in 2D echocardiographyl Assessments in 2D Echocardiography. J Am Coll Cardiol 2016 Nov 29;68(21):2287-2295 [FREE Full text] [doi: 10.1016/j.jacc.2016.08.062] [Medline: 27884247]

89. Kiral-Kornek I, Roy S, Nurse E, Mashford B, Karoly P, Carroll T, et al. Epileptic seizure prediction using big data and deep learning: toward a mobile system. EBioMedicine 2018 Jan;27:103-111 [FREE Full text] [doi: 10.1016/j.ebiom.2017.11.032] [Medline: 29262989]

90. Rajkomar A, Oren E, Chen K, Dai AM, Hajaj N, Hardt M, et al. Scalable and accurate deep learning with electronic health records. Digit Med 2018;1:18.

91. Hsiao P, Chin-Ming CH, Li Y. Applied wearable devices for digital health based on novel cardiac force index of running performance:cross-sectional study. JMIR mHealth and uHealth (forthcoming). [doi: 10.2196/15331]

92. Health Data Exploration-Personal Data for the Public. 2014. Personal Data for the Public Good: New Opportunities to Enrich Understanding of Individual and Population Health URL: http://hdexplore.calit2.net/wp-content/uploads/2015/08/ hdx_final_report_small.pdf [accessed 2020-02-13]

93. Knight Lab. Personal Health Data as Public Good URL: https://knightlab.ucsd.edu/wordpress/?page id=19 [accessed 2020-02-13]

94. Bakar Institute. Bringing the Power of Computation to Today's Spectrum of Data Will Yield Untold Health Insights and Patterns URL: https://bakarinstitute.ucsf.edu/research/ [accessed 2020-02-13]

95. Digiconomist. Bitcoin Energy Consumption Index URL: https://digiconomist.net/bitcoin-energy-consumption [accessed 2020-02-13]

96. Crush Crypto. What is Practical Byzantine Fault Tolerance (PBFT)? URL: https://crushcrypto.com/ what-is-practical-byzantine-fault-tolerance/ [accessed 2020-02-13]

97. Milutinovic M, He W, Wu H, Kanwal M. Proof of Luck: An Efficient Blockchain Consensus Protocol. In: Proceedings of the 1st Workshop on System Software for Trusted Execution. 2016 Presented at: SysTEX'16; December 12-16, 2016; Trento, Italy. [doi: 10.1145/3007788.3007790]

98. Ismail L, Materwala H, Zeadally S. Lightweight blockchain for healthcare. IEEE Access 2019;7:149935-149951. [doi: 10.1109/access.2019.2947613] 
99. Dorri A, Kanhere SS, Jurdak R. Towards an Optimized BlockChain for IoT. In: Proceedings of the Second International Conference on Internet-of-Things Design and Implementation. 2017 Presented at: IoTDI'17; April 18-21, 2017; Pittsburgh, Pennsylvania. [doi: 10.1145/3054977.3055003]

\author{
Abbreviations \\ EHR: electronic health record \\ eHealth: electronic health \\ IoT: Internet of Things \\ mHealth: mobile health

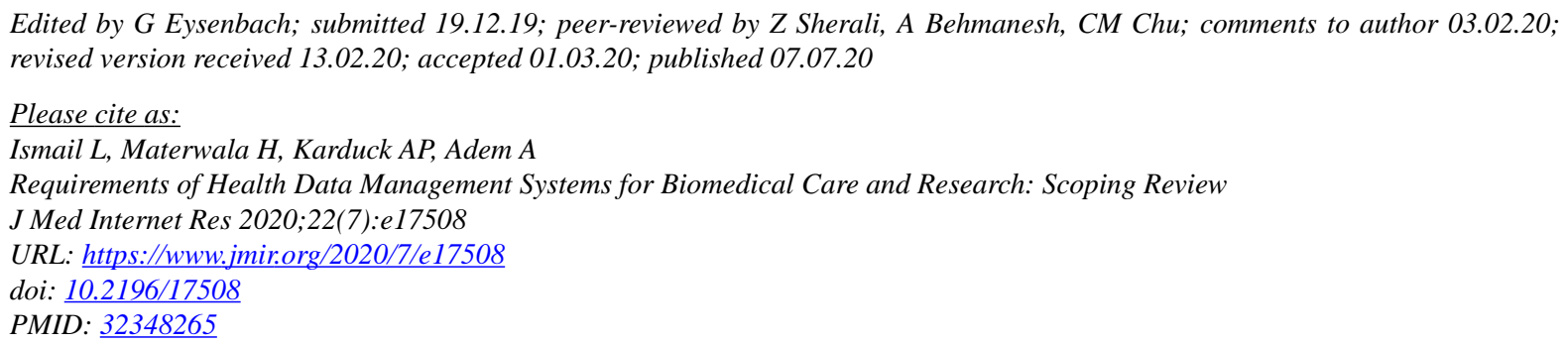

CLeila Ismail, Huned Materwala, Achim P Karduck, Abdu Adem. Originally published in the Journal of Medical Internet Research (http://www.jmir.org), 07.07.2020. This is an open-access article distributed under the terms of the Creative Commons Attribution License (https://creativecommons.org/licenses/by/4.0/), which permits unrestricted use, distribution, and reproduction in any medium, provided the original work, first published in the Journal of Medical Internet Research, is properly cited. The complete bibliographic information, a link to the original publication on http://www.jmir.org/, as well as this copyright and license information must be included. 